\title{
ANALYSIS OF THE COMPETITIVENESS OF THE SECTOR OF SMALL AND MEDIUM ENTERPRISES AND ENTREPRENEURS IN THE REPUBLIC OF SERBIA
}

\author{
MILANOVIC Jelena ${ }^{1}$
}

${ }^{I}$ Agricultural University Plovdiv, Faculty of Economics (BULGARIA)

Email: ekskurzije@vivatravel.rs

\begin{abstract}
The sector of small, medium companies and entrepreneurs (SMEs) has an important role in the economic development of countries around the world. The advantage of this sector lies in its flexibility, quick adaptation to change and the quality of satisfying the modern, increasingly demanding market. Through the sector of small, medium entreprises and entrepreneurs it is possible to develop a competitive economy based on innovations, knowledge and new technologies and influence the competitiveness of the Republic of Serbia.

The aim of this paper is to point out the importance of improving the competitiveness and innovation of the SMEs sector for the future economic development of the national economy.
\end{abstract}

Keywords: competitiveness, SMEs, Serbia

JEL: L26

UDC: $339.137 .2: 330.341 .1(497.11) .005 .52: 334.713$

COBISS.SR-ID: 18201097

\section{Introduction}

The SME sector is one of the key factors of the modern economic development. The attention of many authors has been directed in the direction of this sector due to the fact that, in the fast changing and increasingly competitive global business environment, the small and medium enterprises (SME's) exert a strong influence on the economies of many countries and are considered as the engine of economic growth and technological progress [1]. Their importance is reflected in significant flexibility, but also in increasing the efficiency of inputs utilization [25].

Authors [2], [3], [4] consider this sector to have an important role in the creation of new jobs, the development of an entrepreneurial spirit, the development of innovation in a country and as such is essential for economic growth, employment and the mitigation of poverty. The recent developments of SME's and increasing their numbers in a market economy has proved the strategic importance of this sector for the following reasons [5]:

1. Supporting the development of SME's helps the reconstruction of the larger inefficient enterprises;

2. SME's mitigate the monopoly of large enterprises and offer competitive goods and services in accordance with the changes in modern economies;

3. Small industrial enterprises produce goods mainly for the domestic market, utilizing mainly national resources, thus stimulating the national economy.

The development of new technologies, and business venvironment of the new age have resulted in the need for the application of strategic management [27] as a 'tool' which, in a swiftly changing environment, can help organizations achieve their objectives more 
efficiently and effectively by understanding their internal and external environments [28]. In the modern business environment, competitiveness represents the key to success of every enterprise. Many scientists consider that competitive advantage is achieved by acquiring a superior position in the market. This superiority depends on the consumers and therefore it can be observed and analyzed from their perspective [18]. One of the definitions of competitiveness is that competitiveness implies the improvement of stature of an individual, company and state compared to other similar entities [6]. Therefor a huge number of SME's is competing against competitors on both the domestic and the international markets. The development of entrepreneurial talent is of paramount importance when it comes to sustaining competitive advantage on the global market and in circumstances of the new economy, which is being catalyzed by innovations [19]. Spremo [7] considers that the competitiveness of a country is influenced by many factors, but the key factor is the competitiveness of the companies, them carrying the economy development

\section{Characteristics of the SMEs Sector in the Republic of Serbia}

In the economic politics of the European Union small and medium companies play a central role. By implementing the Lisbon strategy in 2000 a strategic approach in the development of the SMEs has begun with the goal of making the European Union the most competitive economy by 2010 . However, the implementation of the goals that were set did not follow an expected pace, partially due to the worsening of the world economic situation and the increased competitiveness of new economic powers, but also due to the slow progress of reforms in the EU countries themselves [8]. Unfulfilled strategic goals of the EU set in 2000 have brought forward the creation of a new strategic development framework for the period from 2010 to 2020 called "Europe 2020", focused on the following strategic priorities [9]:

- Smart development - development of an economy based on knowledge and innovations (scientific and technological research and development, innovations, education and digital society);

- Sustainable development - at the same time, encouraging competitiveness and production which would utilize resources more efficiently;

- Inclusive growth - better participation on the job market, fight against poverty and social cohesion.

During 2009 Serbia has faced the world economic crisis, due to the cessation of positive economic development trends and which had an effect of declining business and foreign exchange activity, growth of unemployment, reduction of investments etc. Besides the crisis, transitional processes and business restructuring have had an impact on the reduction of employed citizens without having a significant investment cycle planned, which should have engaged the free work force. The question of efficiency of business systems and economy subjects is even more emphasized in the cyclic occurrence of global economic crises and demands the reconsideration of strategies and growth policies on every level [10].

The analysis of the SMEs is a very current topic in all countries. As the SMEs is the source of the birth of successful entrepreneurial ideas [23], many authors have analyzed the SME sector in their studies [10], [20], [21], [22], [24], [26], [29].

It is estimated that the SMEs account for $99,8 \%$ of active business subjects, provide two thirds of employment and turnover in the non-financial sector, provides $43,2 \%$ of exports in the non-financial sector and generates $32 \%$ of the Serbian GDP. Average number of employees in the SMEs is 2,4 which shows one of the key weaknesses of this sector compared to the member states of the EU, where the average number of employees is 4,2 [11]. 
Graph 1. shows the number of companies and the number of employees in the last two years (2018 and 2019).

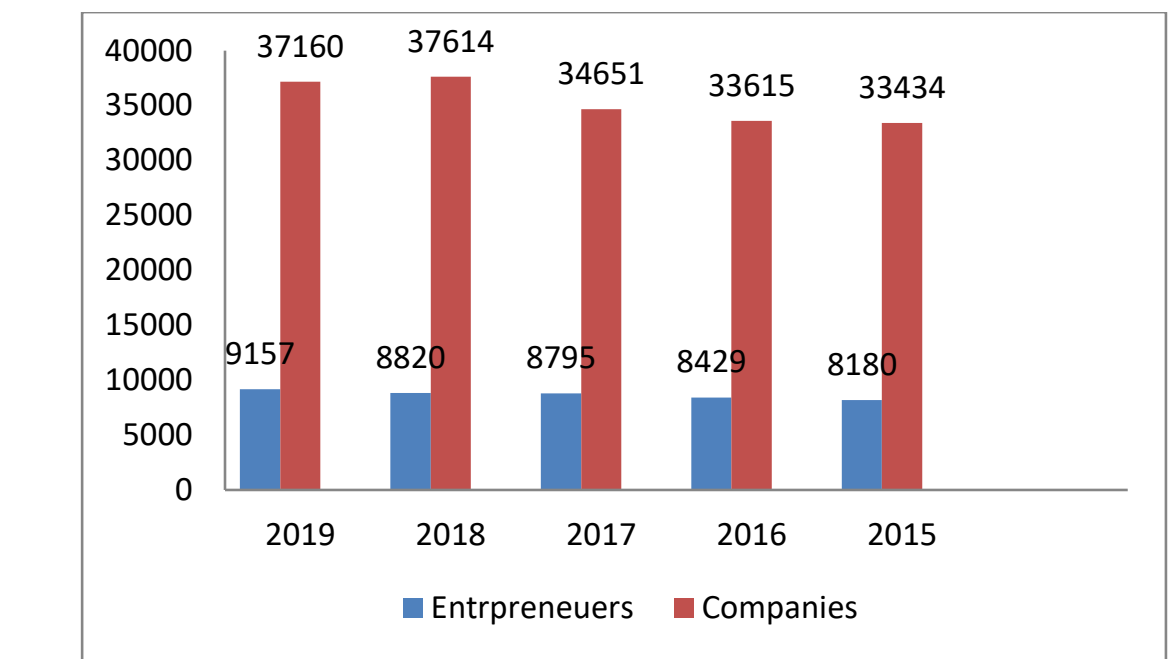

Graph 1. Number of newly established companies and entrepreneurs (2018-2019) [12]

The SMEs sector of Serbia has been noted to be growing in the past several years. Graph 1 shows the number of newly established companies and entrepreneurs in the time period of 2015-2019, according to the Business Registers Agency. Fig. 1. shows the number of companies and the number of employees in the last two years (2018 and 2019)

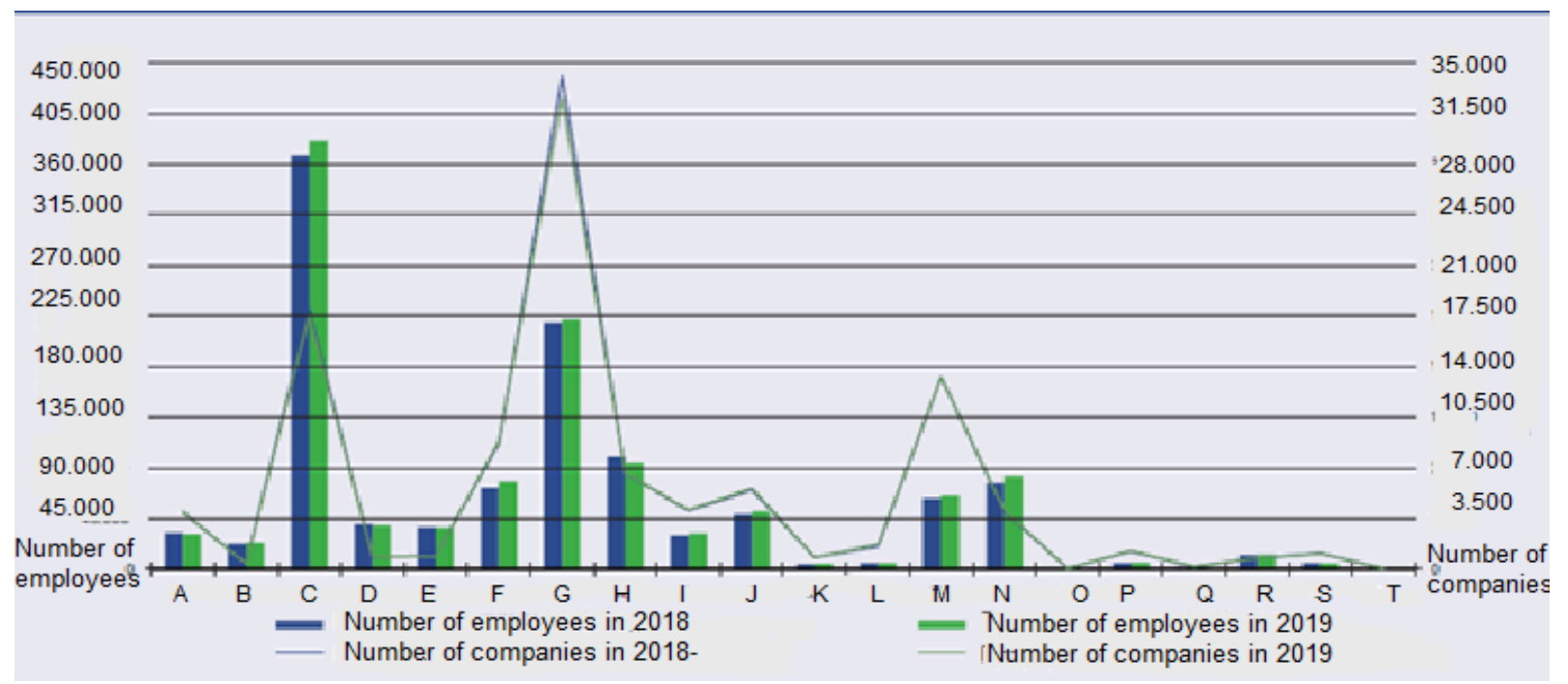

Fig. 1. The number of companies and the number of employees in the last two years (2018 and 2019) [13]

Interchangeable sectors: A - Agriculture, forestry and fishing; B - Mining; C Manufacturing industry; D - Providers of electricity, gas, steam and air conditioning; E Water, waste water management and process control. Non-interchangeable resources: F Construction; $\mathrm{G}$ - Retail and wholesale, vehicle and motorcycle repair; $\mathrm{H}$ - Traffic and warehousing; I - Accommodation, lodging and food service providers; $\mathrm{J}$ - Information and communication; K - Finances and insurance; L - Real estate; M - Professional, scientific, innovative and technical activities; $\mathrm{N}$ - Administrative and auxiliary service activities; $\mathrm{O}$ State administration and defense, compulsory social security; R - Education; Q - Healthcare and social care; $\mathrm{R}$ - Art, leisure and recreation; $\mathrm{S}$ - Other service activities; $\mathrm{T}$ - Homemaking 
as employment, Homemakers as producers of goods and services for their own needs; U Activities of extraterritorial organizations and bodies.

Sector S - Manufacturing has had the most employees, followed closely by sector $\mathrm{G}-$ Retail and wholesale.

According to the number of companies, prominent sectors are sector $\mathrm{G}-$ Retail and wholesale (32.560 or $31,2 \%$ ) and C - Manufacturing industry (17.548 or $16,8 \%)$, followed by the sector $\mathrm{M}$ - Professional, scientific, innovative and technical activities (13.255 or 12,7\%), even though the number of companies in those sectors has declined compared to the previous year (approximately 1.514, 421 i 10 companies respectively) [13].

\section{Competitiveness of SME's in the Republic of Serbia}

In order to increase their competitive ability, the companies need to restructure in order to face the demands of modern business and to become more productive and competitive [14].

According to the definition of OECD, competitiveness is the measure of capability of a country to produce goods and services passing the test of the international market in free and equal market conditions, while at the same time retaining and increasing in the long term the real income of the citizens. The European Commission (1994) has defined competitiveness as: expressed capacity of the companies, industrial regions, nations or supranational associations and as such kept, in order to secure the international competitiveness, to secure a relatively high return of the production factors and a relatively high level of employment on a sustainable basis.

In the Republic of Serbia, based on the principle of the "Small Business Act for Europe" SBA (current framework for the development of SMC's in the European Union), the Strategy for the support of development of SMC's and competitiveness has been enacted for the time period of 2015. to 2020 .

The strategy defines 6 strategic points which have been further elaborated through specific goals. These strategic goals correspond to the pillars of the Strategy [15]:

I. Improvement of the business environment;

II. Improvement of access to the sources of financing;

III. Continuous development of human resources;

IV. Strengthening of sustainability and competitiveness of SME's;

V. Improved access to new markets;

VI. Development and promotion of the entrepreneurial spirit and enticing the entrepreneurship with women, youth and social entrepreneurship.

Strengthening of sustainability and competitiveness of SME's, the fourth pillar of the Strategy has four dimensions:

1. The first dimension: Increasing the efficiency of the institutional support to the business and development of the SME's;

2. The second dimension: The optimization and improvement of the utilization level of existing, and the development of new business infrastructure;

3. Strengthening the innovativeness of the SME's;

4. Stimulation of the business cooperation and creating the chains of value.

In order to control the success of the implementation of the Strategy, precise and measurable indicators have been set with the goal of checking whether the planned goal has been achieved. Table 1. [16] shows the achieved values in the period from 2008 to 2013 and the planned values for the period from 2015 to 2020. For the period from 2008 to 2013 the real average yearly turnover growth rate of SME's was $-2,9 \%$, while the planned turnover growth rate for the period from 2015 to 2020 is $4,0 \%$. 
Table 1. Indicators for tracking the strategic goal - Strengthening the sustainability and competitiveness of SME's [16]

\begin{tabular}{|l|l|l|l|}
\hline \multicolumn{4}{|c|}{ Strengthening of sustainability and competitiveness of SME's } \\
\hline $\begin{array}{l}\text { Real average annual } \\
\text { turnover growth rate of } \\
\text { the SME's }\end{array}$ & $\begin{array}{l}(2008-2013 .) \\
-2,9 \%\end{array}$ & $\begin{array}{l}(2015-2020 .) \\
4,0 \% \pm 1\end{array}$ & $\begin{array}{l}\text { Produced indicators - } \\
\text { Statistical Office of the } \\
\text { Republic of Serbia }\end{array}$ \\
\hline $\begin{array}{l}\text { Annual turnover growth } \\
\text { rate of the SMC's with } \\
\text { manufacturing or } \\
\text { processing innovations }\end{array}$ & $10,1 \%(2013)$. & $13 \%$ & $\begin{array}{l}\text { Inovation Union } \\
\text { Scoreboard }\end{array}$ \\
\hline $\begin{array}{l}\text { Annual turnover growth } \\
\text { rate of the SME's with } \\
\text { marketing or } \\
\text { organizational } \\
\text { innovations }\end{array}$ & $11,7 \%(2013)$ & $14 \%$ & $\begin{array}{l}\text { Inovation Union } \\
\text { Scoreboard }\end{array}$ \\
\hline $\begin{array}{l}\text { Quality of the local } \\
\text { suppliers }\end{array}$ & $\begin{array}{l}\text { Rang 98/144 } \\
(2014-2015)\end{array}$ & In the first 60 & $\begin{array}{l}\text { Global Competitiveness } \\
\text { Index }\end{array}$ \\
\hline
\end{tabular}

Source:[16]

By analyzing the data, none of the four set indicators of the fourth pillar have not been fulfilled yet, though there was significant improvement within the third and fourth indicator.

Table 2. Review of progress in achieving Pillar IV indicators [16]

\begin{tabular}{|l|l|l|l|l|}
\hline Indicator & Initial value & Targeted Value & Current value & Source of data \\
\hline $\begin{array}{l}\text { Real average annual } \\
\text { turnover growth rate } \\
\text { of the SME's }\end{array}$ & $\begin{array}{l}(2008-2013 .) \\
-2,9 \%\end{array}$ & $\begin{array}{l}(2015-2020 .) \\
4,0 \% \pm 1\end{array}$ & $2,18 \%$ & $\begin{array}{l}\text { Produced indicators - } \\
\text { Statistical Office of the } \\
\text { Republic of Serbia } \\
\text { (2013-2016.) }\end{array}$ \\
\hline $\begin{array}{l}\text { Annual turnover } \\
\text { growth rate of the }\end{array}$ & $10,1 \%(2013)$. & $13 \%$ & $6,6 \%$ & $\begin{array}{l}\text { Inovation Union } \\
\text { Scoreboard }\end{array}$ \\
$\begin{array}{l}\text { SMC's with } \\
\text { manufacturing or } \\
\text { processing } \\
\text { innovations }\end{array}$ & $11,7 \%(2013)$ & $14 \%$ & $12 \%$ & \\
\hline $\begin{array}{l}\text { Annual turnover } \\
\text { growth rate of the } \\
\text { SME's with } \\
\text { marketing or } \\
\text { organizational } \\
\text { innovations }\end{array}$ & $\begin{array}{l}\text { Rang 98/144 } \\
(2014-2015)\end{array}$ & In the first 60 & $\mathbf{7 9 / 1 3 7}$ & Scoreboard \\
\hline $\begin{array}{l}\text { Quality of the local } \\
\text { suppliers }\end{array}$ & & & & $\begin{array}{l}\text { Global Competitiveness } \\
\text { Index }\end{array}$ \\
\hline
\end{tabular}

Due to the changes in the methodology Innovation Union Scoreboard, and in order to improve the accuracy of measuring, the indicators should be harmonized with the new methodology. The global competitiveness index for 2018 has also changed the methodology, it no longer estimates the quality of the local suppliers, which implies that this indicator must be harmonized with the new methodology.

The report on SME's for the 2017. shows that the total competitiveness of the SME's is inviolably affected by the industrial competitiveness (which represents the basis of export competitiveness).

Competitive advantages, unlike the comparative advantages, are based on the entrepreneurial environment, education, structure, quality of production and infrastructure, which in a way presents the opportunity for the growth of productivity, export and investment. It is necessary to identify the key factors which would stimulate the restructuring 
of the real sector and which would have an effect of increasing the overall competitive potential of Serbia.

The level of competitiveness of the SME's sector of Serbia falls behind significantly compared to the EU-28 average, as indicated by the comparative analysis of quantity indicators of business (employment per company, GVA per employee). The average number of employees per company in the SME's sector of Serbia is 2,4, while in the countries of EU28 it is 4,0. Also, the productivity of the SME 's sector in Serbia is significantly lower (approximately 3,5 times less) compared to the average of EU-28.

Table 3. shows the business indicators of Serbia, the EU countries and neighbor countries (Slovenia, Romania, Bulgaria, Croatia, Hungary) of Serbia for 2015. and 2016 [17].

Table 3. The business indicators of Serbia, the EU countries and neighbor countries of Serbia for 2015.

\begin{tabular}{|c|c|c|c|c|c|c|c|c|c|}
\hline \multirow[t]{2}{*}{ Country } & \multirow[t]{2}{*}{ Years } & \multirow[t]{2}{*}{$\begin{array}{l}\text { Number of } \\
\text { companies }\end{array}$} & \multirow{2}{*}{$\begin{array}{l}\text { Number of } \\
\text { employees } \\
\text { (thousand) }\end{array}$} & \multirow{2}{*}{$\begin{array}{l}\text { BVD } \\
\text { (GDP?) } \\
\text { (billion } \\
\text { EUR) }\end{array}$} & \multirow{2}{*}{$\begin{array}{l}\text { Number of } \\
\text { employees } \\
\text { per } \\
\text { company }\end{array}$} & \multirow{2}{*}{$\begin{array}{l}\text { BDV } \\
\text { (GDP?) per } \\
\text { employee } \\
\text { (thousand } \\
\text { EUR) }\end{array}$} & \multicolumn{3}{|c|}{$\begin{array}{l}\text { Involvement of SMEs in the non- } \\
\text { financial sector }\end{array}$} \\
\hline & & & & & & & $\begin{array}{l}\text { Number } \\
\text { of } \\
\text { companies }\end{array}$ & $\begin{array}{l}\text { Number } \\
\text { of } \\
\text { employees } \\
\text { (thousand) }\end{array}$ & $\begin{array}{l}\text { GVA } \\
\text { (billion } \\
\text { EUR) }\end{array}$ \\
\hline \multirow[t]{2}{*}{ EU-28 } & 2016 & 23.171 .3 & 91.738 .8 & $4.045,4$ & 4,0 & 44,1 & 99,8 & 66,8 & 57,4 \\
\hline & 2015 & $23.500,3$ & $91.178,8$ & $3.971,5$ & 3,9 & 43,6 & 99,8 & 66,3 & 56,5 \\
\hline \multirow[t]{2}{*}{ Bulgaria } & 2016 & 336,0 & $1.467,7$ & 15,7 & 4,4 & 10,7 & 99,8 & 74,8 & 63,3 \\
\hline & 2015 & 326,2 & 1429,4 & 14,9 & 4,4 & 10,4 & 99,8 & 74,8 & 64,5 \\
\hline \multirow[t]{2}{*}{ Croatia } & 2016 & 147,5 & 692,3 & 13,5 & 4,7 & 19,5 & 99,7 & 69,4 & 61,4 \\
\hline & 2015 & 146,6 & 687,5 & 12,4 & 4,7 & 18,0 & 99,7 & 69,5 & 58,5 \\
\hline \multirow[t]{2}{*}{ Hungary } & 2016 & 551,2 & $1.860,4$ & 30,3 & 3,4 & 16,3 & 99,8 & 69,6 & 53,5 \\
\hline & 2015 & 536,6 & $1.811,1$ & 29,5 & 3,4 & 16,3 & 99,8 & 69,8 & 53,1 \\
\hline \multirow[t]{2}{*}{ Romania } & 2016 & 465,6 & $2.600,1$ & 31,9 & 5,6 & 12,3 & 99,6 & 65,4 & 52,8 \\
\hline & 2015 & 458,1 & $2.551,6$ & 28,5 & 5,6 & 11,2 & 99,6 & 65,5 & 52,3 \\
\hline \multirow[t]{2}{*}{ Slovenia } & 2016 & 138,9 & 440,7 & 13,3 & 3,2 & 30,2 & 99,8 & 72,9 & 64,6 \\
\hline & 2015 & 134,7 & 435,7 & 12,4 & 3,2 & 28,5 & 99,8 & 73,7 & 64,2 \\
\hline \multirow[t]{3}{*}{ Serbia } & 2017 & 357,2 & 873,5 & 10,9 & 2,4 & 12,5 & 99,9 & 66,0 & 56,7 \\
\hline & 2016 & 340,1 & 837,5 & 9,9 & 2,5 & 11,8 & 99,9 & 65,7 & 56,2 \\
\hline & 2015 & 324,6 & 801,7 & 9,1 & 2,5 & 11,3 & 99,8 & 65,7 & 57,7 \\
\hline
\end{tabular}

Comparative performance indicators of the SMEs sector (employment per enterprise and productivity) are significantly lower compared to the EU average and most of the observed countries in the region. In 2016, SMEs in Serbia employ an average of 2.5 workers per company, which is less than the average of the EU-28 (4.0 workers) and all neighboring countries. The productivity of SMEs in Serbia is 3.7 times lower than the EU-28 average (2.4 times that of Slovenia), and of the surrounding countries it is higher only than Bulgaria.

\section{Conclusion}

In order to achieve an efficient competitive advantage, entrepreises should strive to be in front of the others in their search for innovative and hard to imitate ideas. Only those companies which systematically strengthen their competitive position could remain in business. Competitive advantage could to a large degree be achieved through constant striving for a greater level of innovation and efficiency improvement. Improving the competitiveness of this sector is largely determined by supporting the competitiveness of the national economy, especially by improving key parameters in those segments where the Republic of Serbia has competitive shortcomings. Small and medium enterprises, because of their flexibility and they have a good precondition to develop innovation and thus ensure market competitiveness. 
The flexibility of small and medium enterprises in particular comes to mind expression in periods of slowing economic activity and crisis. In order to speed up economic recovery and growth and increase the economic well-being of its inhabitants, the Republic of Serbia must create conditions for better export positioning of its economy. Positive experiences of small business on economic growth and development industrialized countries indicate that one of the strategic.

The goals of the Republic of Serbia should be the faster development of SMEs as a modern concept of small business development and export potential of the economy.

\section{REFERENCES}

[1] Bruque, S., \& Moyano, J. (2007). Organizational determinants of information technology adoption and implementation in SMEs: the case of family and cooperative firms. Technovation, 27(5), pp. 241-253.

[2] Reijonen, H., \& Komppula, R. (2007). Perception of success and its effect on small firm performance. Journal of Small Business and Enterprise Development, 14(4), pp. 689-701. https://doi.org/10.1108/14626000710832776

[3] Ayyagari, M., Beck, T., \& Demirguc-Kunt, A. (2007). Small and medium enterprises across the globe. Small Business Economics, 29(4), pp. 415-434. https://doi.org/10.1007/s11187-006-9002-5 7.

[4] Wadood, F., Shamsuddin, A., \& Abdullah, N. H. (2013). Characteristics of Innovative SMEs in Pakistan: A Case Study. IOSR Journal of Business and Management (IOSR-JBM), 14(6), pp. 45-51.

[5] Bandur M. (2016 "SIGNIFICANCE AND ROLE OF SMALL AND MIDDLE ENTREPRISES IN ECONOMIC DEVELOPMENT” Economics, ISSN 2303-5005, Vol. 4, No 1, pp. 89-105.

[6] Njegovan Z. (2013) "Jačanje regionalne konkurentnosti u uslovima tranzicije” III Naučno stručni skup "Preduzetništvo, inženjerstvo i menadžment" Zrenjanin, Zbornik radova, pp. 13-33.

[7] Spremo T. (2014) "Uloga malih I srednjih preduzeća u funkciji bržeg oporavka privrede Republike Srpske" Ekonomski pogledi, Vol. 16, br. 2, str. 17-29

[8] Katić A., Ćosić I., Raletić S., Vidicki Đ. (2011) ULOGA ZNANJA U POVEĆANJU NACIONALNE KONKURENTNOSTI, XVII Skup TRENDOVI RAZVOJA: "EVROPA 2020: društvo zasnovano na znanju" Kopaonik, 07.-10. 03. 2011., Paper No. A1. 1-6, pp. 1-4.

[9] Kronja J., Avlijaš S., Matejić V., Todić D., Kovačević A., Branković J. (2011) "Vodic kroz strategiju 2020" Evropski pokret u Srbiji, Beograd.

[10] Ivković, D., Čukanović Karavidić, M. \& Vujičić, S. (2012) Mala i srednja preduzeća kao faktor razvoja privrede Srbije. Ekonomska analiza, br. 3-4, pp. 31-45.

[11] https://www.mfin.gov.rs/UserFiles/File/strategije/ERP\%202017-2019(1).pdf

[12] https://www.apr.gov.rs/\%D0\%B8\%D0\%BD\%D1\%84\%D0\%BE\%D0\%B3\%D1\%80\%D0\%B0\%D1\%84 $\% \mathrm{D} 0 \% \mathrm{~B} 8 \% \mathrm{D} 0 \% \mathrm{BA} \% \mathrm{D} 0 \% \mathrm{~B} 5.4318 . \mathrm{html}$ ?infoId=7

[13] Agencija za privredne registre (2020) Godišnji izveštaj o poslovanju privrede 2019., Beograd.

[14] Trbović A., Drašković B., Lalić D. (2013) "Pravci promene kadrovske politike preduzeća kao vid jačanja konkurentnosti u kontekstu svetske ekonomske krize” Teme, G. XXXVII, Br. 1 pp. 203-221.

[15] https://privreda.gov.rs/wp-content/uploads/2018/03/Strategija-I-Plan.pdf

[16] Miljenovic R. (2019) Strategija za podršku razvoja malih i srednjih preduzeća, preduzetništva i konkurentnosti za period od 2015. do 2020. godine sa Akcionim planom - Analiza efekata i potreba za revizijom (mid-term evaluacija), Nemačke organizacije za međunarodnu saradnju (GIZ) i Nemačkosrpske inicijativa za održivi razvoj i zapošljavanje https://cep.org.rs/wp-content/uploads/2019/10/Midterm-evaluation-of-SME-Strategy_final_srp.pdf

[17] Ministarstvo privrede, Sektor za razvoj malih i srednjih preduzeća i preduzetništva (2018) Izveštaj o malim i srednjim preduzećima i preduzetništvu za 2017. Godinu.

[18] Radovic Markovic M., Salamzadeh A., Vujicic S. (2019) Selection of organization models and creation of competences of the employed poeple for the sake of competitiveness growth in global businessenvironment, International Review, No.1-2. ISSN 2217-9739, pp. 64-71.

[19] Radovic Markovic M., Lutovac M., Vujicic S. (2016) "Efekat preduzetničkog obrazovanja na razvoj preduzetničkih sposobnosti mladih” Trendovi u poslovanju, ISSN 2334-816X, No. 7, Vol. 1, Visoka poslovna škola "Prof.dr Radomir Bojković” Kruševac.

[20] Vujicic S., Tosović Stevanović A., Ristanovic V. (2019) THE ROLE OF SMALL AND MEDIUMSIZED ENTERPRISES IN THE DEVELOPMENT OF THE REPUBLIC OF SERBIA, $41^{\text {st }}$ International Scientific Conference on Economic and Social Development - Belgrade, 23-24 May 2019.

[21] Milosevic D., Vujicic S. (2015) Menadzment malih i srednjih preduzeća, Viska škola za poslovnu ekonomiju i preduzetništvo, Beograd. 
[22] Aničić J., Aničić D., Vasić N. (2017) Razvoj preduzetništva i finansijske performanse sektora MSP u Srbiji, Ekonomika, Društvo ekonomista “Ekonomika”, Niš, vol. 63, br. 4, str. 29-39.

[23] Ilic Đ., Ilic S. (2018). Specifičnosti finansiranja proizvodnih malih i srednjih preduzeća, Trendovi u poslovanju, ISSN 2334-816X, No. 12, Vol. 2, Visoka poslovna škola "Prof.dr Radomir Bojković", Kruševac.

[24] Vujičić, S., Nikitović, Z., \& Cogoljević, D. (2016). 1.8. THE ROLE OF SMALL AND MEDIUM ENTERPRISES AND ENTREPRENEURS IN THE REDUCTION OF UNEMPLOYMENT IN THE REPUBLIC OF SERBIA. IMPACT OF ECONOMIC POLICIES ON ATTAINING RESILIENT GROWTH BOOK OF ABSTRACTS, 50.

[25] Popović B., Ceranić S., Paunović T. (2016) Primena I - odstojanja i koeficijenta separabilnosti u oceni poslovanja MSP u agrobiznisu, Ekonomika poljoprivrede, Naučno društvo agrarnih ekonomista Balkana, Beograd i Institut za ekonomiku poljoprivrede, Beograd i Akademija ekonomskih nauka, Bukurešt, vol. 63, br. 3, str. 1039-1052.

[26] Vujicic S., Ravic N., Nikitovic Z. (2019) Menadžment malih i srednjih preduzeća, Visoka škola za poslovnu ekonomiju i preduzetništvo, Beograd.

[27] Rabrenovic' M. (2011) Strategijski menadžment u javnom sektoru Beograd: JP 'Glasnik' \& Eurosfera; 2011.

[28] Rabrenovic M., Cukanovic Karavidic M., Stosic I. (2018) Association of strategic management with vaccination in the terms of globalization, International Journal for Quality in Health Care, Oxford University Press, Volume 30, Issue 3, April 2018, pp. 234-239.

[29] Nikitovic Z. Vujicic S. (2019) Preduzetništvo, Visoka škola za poslovnu ekonomiju i preduzetništvo, Beograd.

\section{Article history:}

Received 25 May 2020

Accepted 30 Juny 2020 